\title{
Jakiej płci są piłkarzy(n)ki? Żeński futbol i antropologia zaangażowana
}

\author{
Wika Krauz \\ Szkoła Doktorska Nauk Humanistycznych UW
}

DOI: http://dx.doi.org/10.18778/1733-8069.17.1.05

Słowa kluczowe:

antropologia

sportu, piłka nożna,

antropologia

płci, sztuka ze

społecznością,

antropologia

zaangażowana

\begin{abstract}
Abstrakt: Artykuł dotyczy projektu „Piłkarzy(n)ki” - queerowo-feministycznej interwencji artystycznej i obiektu do gry stworzonego z lokalną społecznością Poznania. Projekt ten powstał w wyniku dwuletnich badań etnograficznych (2016-2018) na temat marginalizacji żeńskiego futbolu w Polsce. Korzystam w nim z metodologii i teorii antropologii zaangażowanej (Scheper-Hughes 1995) oraz badań w działaniu jako sztuki ze społecznością (Červinková 2012; Bishop 2015; Rakowski 2018), poddając jednocześnie te nurty krytycznemu namysłowi. Artykuł pokazuje, jak inicjatywa łącząca badanie oraz działanie pomaga w uchwyceniu głosu dyskryminowanych piłkarek. Opisany projekt jest odpowiedzią na binarny podział płci w futbolu, symboliczną przemoc (Bourdieu, Wacquant 2001) oraz bezpodstawną degradację, której doświadczyły zawodniczki żeńskiej drużyny klubu Kotwica Kórnik. W tekście stawiam tezę, że piłka nożna to społeczna soczewka, która pokazuje, jak ukształtowany jest porządek płci naszego społeczeństwa.
\end{abstract}

Wika Krauz, mgr, absolwentka Instytutu Etnologii i Antropologii Kulturowej UW, doktorantka w Szkole Doktorskiej Nauk Humanistycznych UW. Główne obszary zainteresowań naukowych: antropologia płci i seksualności, sportu, twarzy i ciała, socjologia i antropologia medycyny, feminizm, badania w działaniu, sztuka ze społecznością, autoetnografia.

\section{Adres kontaktowy}

Szkoła Doktorska Nauk Humanistycznych UW

Nauki o Kulturze i Religii

Instytut Etnologii i Antropologii Kulturowej UW

ul. Żurawia 4, 00-503 Warszawa

e-mail: krauzwika@gmail.com

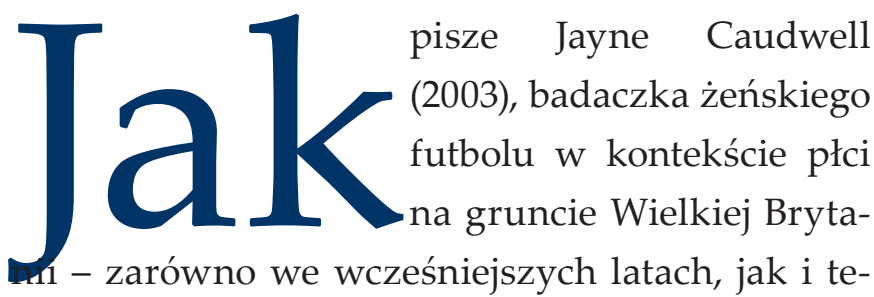

raz, w XXI wieku, uczestnictwo kobiet i dziewcząt w grze w piłkę nożną opiera się głównie na strukturach organizacyjnych oraz praktykach prawnych i dyskursywnych, które różnicują osoby grające w piłkę ze względu na płeć. Kobiety przez lata w ogóle nie miały dostępu do gry w futbol, przez co musiały negocjować oraz stopniowo przekraczać granice powszechnej, binarnej segregacji płciowej 
$\mathrm{w}$ ramach tej dyscypliny i w całym sporcie (Birrell 1988; Pfister 2011). Piłka nożna to przestrzeń silnie związana $\mathrm{z}$ budowaniem męskiego autorytetu oraz rozwijaniem i prezentacją cech czy zdolności, które wyznaczają granice władzy mężczyzn (Jakubowska 2006; zob. Pfister 2011). Jeszcze do lat 70. XX wieku futbol kojarzono głównie z mężczyznami, ale już wówczas charakter uczestnictwa kobiet w piłce nożnej zaczął się nieco zmieniać, między innymi pod wpływem wydarzeń, o których wspomina Kamila Grześkowiak (2014) - zniesiono zakaz organizowania meczów piłki nożnej kobiet wprowadzony w Wielkiej Brytanii w 1921 roku; wprowadzono w USA IX Poprawkę zabraniającą dyskryminacji ze względu na płeć, co dało kobietom formalną możliwość gry w futbol, której wcześniej były pozbawione; w Zurychu w 1973 roku odbyła się pierwsza światowa konferencja poświęcona żeńskiej piłce nożnej organizowana przez UEFA, podczas której podsumowano działania komitetu ds. piłki nożnej założonego w 1971 roku przy tej samej organizacji (zob. Fasting 2003; Jacobs 2004; Williams 2007; Dufur, Linford 2010). W Polsce w tamtym czasie powstała pierwsza kobieca drużyna piłkarska Checz Gdynia, ale na jakiekolwiek większe zmiany w tym sektorze rodzimego futbolu trzeba było poczekać aż do końca lat 90. XX wieku, kiedy w Poznaniu utworzono kolejne żeńskie zespoły (Grześkowiak 2014).

Pomimo opisanego stanu rzeczy i tego, że współczesne wzorce płciowe ulegają znaczącym przemianom (zob. Hryciuk, Korolczuk 2012), to w polskim, patriarchalnym społeczeństwie wciąż pokutuje przekonanie, że futbol nie jest dla kobiet (por. Dzik 2008; Jakubowska 2013; 2015). Wielokrotnie poruszałam ten temat podczas badań etnograficznych na temat marginalizacji żeńskiego futbolu i taktyk oporu wobec patriarchatu, które prowadziłam w Warszawie w latach 2016-20181. Moje rozmówczynie, piłkarki, przeciwstawiały się nierównemu, lekceważącemu traktowaniu w polskiej piłce, opierały tradycyjnemu podziałowi ról oraz segregacji płciowej i tym samym uświadomiły mi ogromną skalę problemu.

Zdecydowałam, że będę działać z nimi, łącząc kompetencje badaczki, animatorki kultury, aktywistki $\mathrm{i}$ artystki ${ }^{2}$. Dlatego w ramach akademii badawczo-artystycznej „Sąsiedztwo - granice bliskości. Queerowy Demontaż", organizowanej przez poznańskie stowarzyszenie Scena Robocza, w 2019 roku postanowiłam zrealizować projekt „Piłkarzy(n)ki” z lokalnymi piłkarkami z seniorskiej drużyny klubu Kotwica Kórnik. Uznałyśmy, że jest to odpowiedni moment na podjęcie tematu, ponieważ kilka miesięcy przed rozpoczęciem naszego działania zawodniczki wspomnianej grupy doświadczyły bezpodstawnej degradacji ze strony władz swojego klubu ${ }^{3}$. Tym samym projekt stał się nie tylko pretekstem do zadawania pytań o udział osób z doświadczeniem życia jako kobiety w (polskiej) piłce nożnej. Był i jest także odpowiedzią na realny, społeczny problem marginalizowanej grupy, w tym przemoc symboliczna, która polega na transmitowaniu wzorców, zachowań, znaków oraz treści danej kultury, wraz $\mathrm{z}$ narzucaniem ich interpretacji (Bourdieu, Wacquant 2001; Suchocka 2011). Owa przemoc dokonuje się tam, gdzie się jej nie zauważa i opiera się na fakcie

\footnotetext{
${ }^{1}$ Na podstawie wspomnianych badań etnograficznych napisałam pracę magisterską obronioną w Instytucie Etnologii i Antropologii Kulturowej Uniwersytetu Warszawskiego w 2018 r.

${ }^{2}$ Nie zdecydowałabym się na ten krok, gdyby nie fakt, że mam już praktykę $\mathrm{w}$ badaniach $\mathrm{w}$ działaniu rozumianych jako sztuka ze społecznością. W latach 2013-2014 jako część badań do pracy licencjackiej zrealizowałam własny projekt z kobietami na Radomszczyźnie i przez tydzień prowadziłam otwarty, publiczny klub dyskusyjny w lokalnym sklepie. Poruszałyśmy tam tematy takie jak edukacja seksualna, gender czy role kobiet na wsi (zob. Ogrodzka 2020; Rakowski 2018).

${ }^{3}$ Bardziej szczegółowo będę pisać o tej sprawie w dalszych częściach artykułu.
} 
akceptowania przez ludzi podstawowych, bezrefleksyjnych założeń (Bourdieu, Wacquant 2001; Suchocka 2011) - na przykład tego, że mężczyźni rzekomo lepiej grają w piłkę niż kobiety.

W tekście przyjmuję, że „Piłkarzy(n)ki” to interwencja badawczo-artystyczna zrealizowana $\mathrm{w}$ duchu antropologii zaangażowanej - jej celem stało się poznanie i zrozumienie społeczno-kulturowego mikroświata grupy piłkarek oraz prowokowanie przemian tam, gdzie sytuacja zagraża osobom mniej uprzywilejowanym (Scheper-Hughes 1995; Songin-Mokrzan 2013). Opisywane przeze mnie działanie pozwoliło na uchwycenie głosu drużyny, a także dało piłkarkom Kotwicy Kórnik kolejne narzędzie służące demokratyzacji i autoemancypacji,

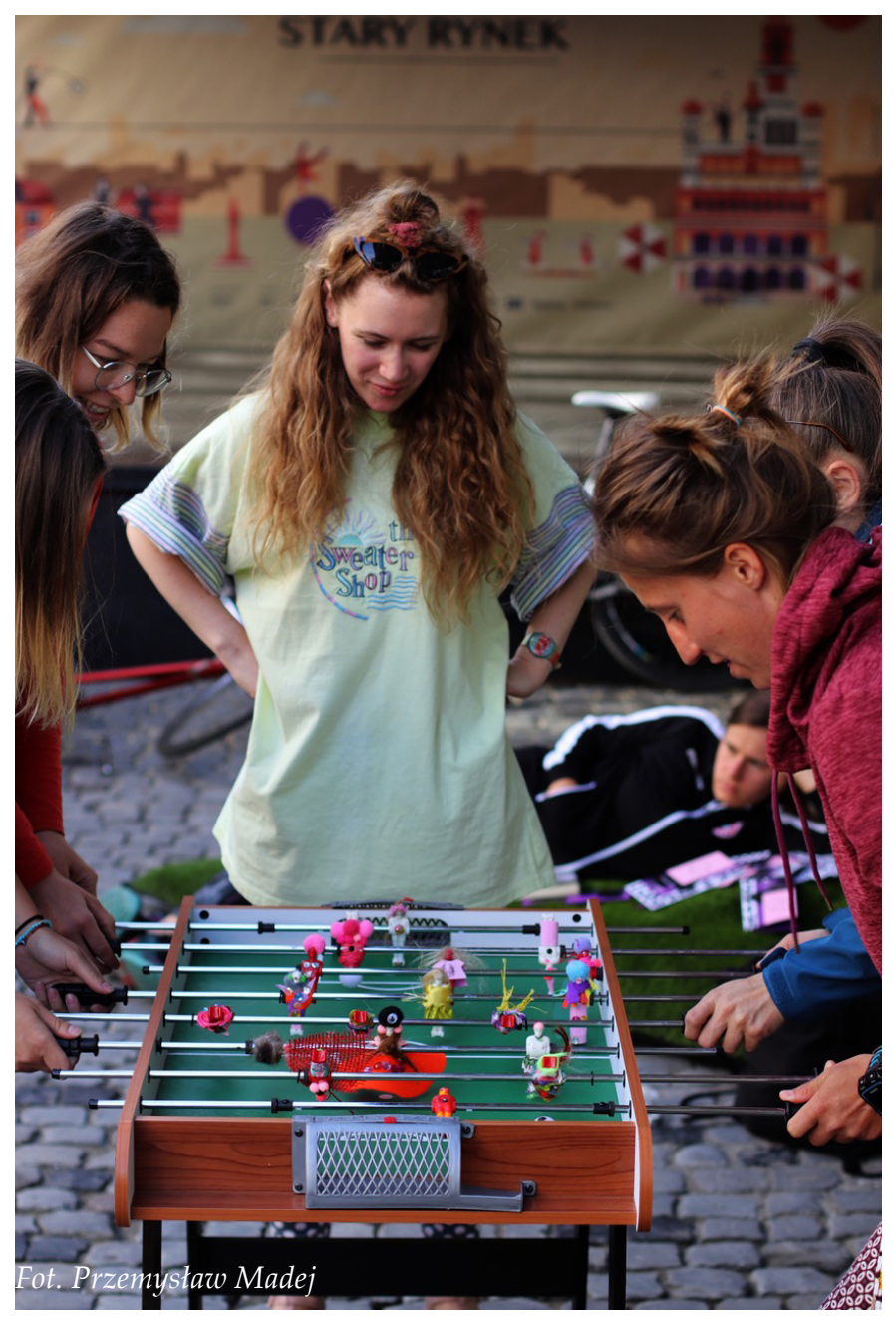

bo takie założenie badań w działaniu jako sztuki ze społecznością przyjmuję na potrzeby tej pracy (Bishop 2015; Rakowski 2018; Wójcik, Stokfiszewski, Jasińska 2018). Publicznie zadałyśmy pytanie, którym wsadzamy kij w mrowisko - o to, jakiej płci są piłkarzy(n)ki. Tym samym zastanawiamy się, dlaczego piłkę nożną w Polsce wciąż kojarzy się przede wszystkim z mężczyznami? Czy publiczne praktyki badawczo-artystyczne moga pomóc w odwróceniu patriarchalnego dyskursu? Postaram się odpowiedzieć na te pytania w swoim artykule.

\section{Z babami o piłce się nie rozmawia}

Caroline Criado Perez (2020) opisuje dyskryminację, marginalizację i pewną nieobecność piłkarek w dyskursie publicznym, analizując teksty na Wikipedii. Autorka wskazuje, że na portalu udostępniono obszerny artykuł dotyczący męskiej drużyny reprezentacji Anglii w piłce nożnej, a o piłkarkach traktuje jedynie podstrona „Kobieca reprezentacja Anglii w piłce nożnej” (Criado Perez 2020). W polskiej wersji jest podobnie. Futbol w Polsce nadal postrzega się przez pryzmat tradycyjnych wzorców skojarzonych z męskością, a kobiecość traktuje nie tyle jako opozycję, ale jako coś, co do męskości nie pasuje i jest wobec niej niszowe (por. Dzik 2008; por. Criado Perez 2020). Żeńską piłkę nożną się odrzuca, marginalizuje i niesłusznie lekceważy, właśnie ze względu na jej "męski” charakter (Jakubowska 2013), który pozbawia i mężczyzn, i kobiety pewnych atrybutów przypisanych im przez płciowe stereotypy, a w konsekwencji generuje pomieszanie ról społecznych. Dyskryminacja kobiecego futbolu wynika najpewniej z silnej obawy mężczyzn przed załamaniem ich hegemonii (zob. Birrell 1988; Connell, Messerschmidt 2005) nie tylko w sporcie, ale ogólnie w sferze publicznej (Collier, Rosaldo, Yanagisako 2007). 
Sytuacja kobiet stopniowo ulegała (i oczywiście wciąż ulega) różnym zmianom, ale niestety nie da się zaprzeczyć, że do dziś ślad dominacji mężczyzn pozostaje, a piłka nożna, szczególnie w Polsce, opiera się na silnej hierarchii płci i ma wyraźnie "męski” charakter (por. Dzik 2008; Jakubowska 2013; 2015). Potwierdzenie tej tezy znalazłam między innymi w wywiadzie przeprowadzonym przez Hannę Urbaniak dla „Gazety Wyborczej” z jedną z najlepszych polskich bramkarek - Katarzyną Kiedrzynek $^{4}$. Rozmowa z Kiedrzynek dotyczyła sytuacji kobiet grających w piłkę nie tylko w Polsce, ale także w innych miejscach na świecie. Bramkarka na pytanie publicystki o to, dlaczego Polacy nie doceniają piłki nożnej kobiet, odpowiedziała:

Nie jesteśmy na to gotowi. Kobieta i piłka nożna wciąż nie idą w Polsce w parze. Byle junior jest bardziej szanowany, bo ludzie widzą w nim wielkie pieniądze. Nie umiemy przyjąć do wiadomości, że kobiety potrafią grać i że mogą to robić, dlatego wciąż je lekceważymy. Masa hejterów krytykuje nas tylko za to, że w ogóle kopiemy piłkę. Nie ma znaczenia nawet to, że osiągamy sukcesy. Każda Polka, która zdecyduje się uprawiać futbol, musi się w życiu nasłuchać wielu epitetów. Ja akurat się tym nie przejmuję, ale wiele z nas ma tego dosyć i rezygnuje z kariery. (wyborcza. pl [dostęp 19 września 2020 r.])

Może się wydawać, że zdaniem Katarzyny Kiedrzynek to głównie kibice nie są "gotowi" na potraktowanie kobiecego futbolu na równi z męskim. Według

\footnotetext{
${ }^{4}$ Aktualnie Katarzyna Kiedrzynek to bramkarka niemieckiego klubu VfL Wolfsburg. W przeszłości grała w prestiżowym francuskim klubie piłki nożnej kobiet Paris Saint-Germain i w reprezentacji Polski, w której pełniła także funkcję kapitanki drużyny. Jako jedyna Polka zagrała (dwukrotnie) w finale Ligi Mistrzyń. Została m.in. określona najlepszą bramkarką przez Ligue 1, piłkarką roku w Plebiscycie Piłki Nożnej i wyróżniona przez UEFA (laczynaspilka.pl; pilkanozna.pl; sport. pl [dostęp 19 września 2020 r.]).
}

mnie jedną z najistotniejszych przyczyn krytyki kobiecej piłki (i lekceważącego stosunku wobec niej) jest to, że piłkarki „ośmielają się" przekraczać kulturowo i społecznie ustalone "granice". Uprawiając sport (tym bardziej taki, który do tej pory zarezerwowany był dla mężczyzn), kobiety na dobre wychodzą poza kulturowo przypisaną sferę domowa, wkraczają do sfery publicznej (por. Collier, Ronaldo, Yanagisako 2007) i w jakiś sposób wewnątrz niej manifestują opór wobec męskiej dominacji. Nie można się jednak zgodzić z tym, że wina leży wyłącznie po stronie kibiców, a instytucje funkcjonują niemal bez zarzutu (do tego jeszcze w poszanowaniu wobec kobiecej piłki nożnej). Moim zdaniem mniej więcej tak próbuje przedstawić sytuację bohaterka wywiadu:

Osobiście duże nadzieje wiążę z prezesem Bońkiem. To pierwszy prezes PZPN, który zainteresował się naszą kadrą. Pomógł nam, gdy byłyśmy w potrzebie. Mocno liczę na jego wsparcie. Liczę, że weźmie się do futbolu kobiecego tak, jak wziął się do szkolenia chłopców. I nie mam na myśli wielkich pieniędzy, bo nam nie potrzeba luksusów. Potrzebujemy kogoś, kto przekona kibiców w Polsce, że piłka kobieca jest warta uwagi. Postawi na nas, pomoże przełamać niechęć. (wyborcza.pl [dostęp 19 września 2020 r.])

Oczywiście zdaję sobie sprawę z tego, że krytyczne uwagi pod adresem prezesa Zbigniewa Bońka albo samego Polskiego Związku Piłki Nożnej byłyby metaforycznym strzałem w stopę - w końcu Kiedrzynek, jako reprezentantka Polski, jest uwikłana w jakąś relację władzy i zależności (m.in. ekonomicznej). Z drugiej strony myślę, że powinna wykorzystać swoją pozycję oraz niewątpliwy autorytet i podjąć próbę walki z dotychczasowym dyskursem. Ten przecież jest w jakimś sensie ustalony, ukształtowany albo odgórnie narzucony przez 
różne instytucje, nie tylko przez PZPN. Michel de Certeau (2008) pisze o tym, że „słabi”, którzy funkcjonują $\mathrm{w}$ polu zorganizowanym przez władzę, mogą okazać swoją siłę, by przejąć kontrolę nad przestrzenią organizacyjną (por. Pawłowska 2017). W tym kontekście „słabymi” stają się głównie kobiety zaangażowane $\mathrm{w}$ grę $\mathrm{w}$ piłkę nożną - $\mathrm{zmu}$ szone do radzenia sobie w rzeczywistości, gdzie ustalone reguły nie zawsze są przez nie akceptowane (de Certeau 2008; Pawłowska 2017). Zdaniem de Certeau (2008) w zachodnim porządku kulturowym istnieją zarówno strategie, za sprawą których generowane są relacje władzy, ale także taktyki, rozumiane jako podstawowe sposoby obrony nieuprzywilejowanych (tzw. słabych), stosowane przeciwko działaniom wspomnianej władzy (por. Pawłowska 2017). Taktyką oporu samą w sobie jest uprawianie przez kobiety sportu, który stereotypowo kojarzy się z mężczyznami. Jednak to, jak widać, nie wystarcza. Być może gdyby więcej entuzjastek dziedziny zjednoczyło się i zaczęło mówić jednym głosem, wówczas zaistniałaby większa szansa na zmianę. Tutaj oczywiście widzę ogromne pole do zagospodarowania działaniami z zakresu antropologii zaangażowanej (Scheper-Hughes 1995) oraz badań w działaniu jako sztuki ze społecznością (Červinková 2012; Bishop 2015; Rakowski 2018), które mogą pomóc w uchwyceniu i integracji głosów osób systemowo dyskryminowanych. Co istotne, marginalizacja kobiecej piłki nożnej nie wynika tylko z patriarchalnego podejścia kibiców, ale także między innymi z uznania podrzędnego statusu kobiet przez ogromne, państwowe instytucje (którym wszyscy w jakiś sposób podlegamy).

W kontekście przytoczonej wcześniej wypowiedzi Katarzyny Kiedrzynek gloryfikacja Zbigniewa Bońka wydawała mi się nie do końca wiarygodna, bo z jego wpisu na Twitterze $\mathrm{z}$ tego samego roku jasno wynikało, że „z babami o piłce się nie rozmawia"5. Prezes Polskiego Związku Piłki Nożnej dał wyraz protekcjonalizmu, paternalizmu oraz braku szacunku i wsparcia nie tylko wobec piłkarek, ale też innych osób z doświadczeniem życia jako kobiety, jakkolwiek zaangażowanych w polski, żeński futbol ${ }^{6}$. Idąc tym tropem nie powinno dziwić, że instytucje sportowe niższego szczebla reprodukują podobny wzorzec i - jak w przypadku kobiecej drużyny klubu Kotwica Kórnik - odbierają zawodniczkom głos w sytuacjach dyskomfortu.

Piłkarki Kotwicy na kilka miesięcy przed rozpoczęciem naszego projektu „Piłkarzy(n)ki” zostały $\mathrm{w}$ środku sezonu oficjalnie zdegradowane przez władze klubu z poziomu I ligi do ligi amatorskiej. $\mathrm{Na}$ podstawie rozmów z zawodniczkami wywnioskowałam, że to wszystko najprawdopodobniej dlatego, bo zaczęły publicznie głośno mówić o przypadkach molestowania seksualnego ze strony jednego z trenerów i domagały się jego odsunięcia ${ }^{7}$. Zarząd Kotwicy bez wiedzy piłkarek z dnia na dzień zamieścił na stronie internetowej klubu oświadczenie, w którym umotywował swoją decyzję niewystar-

\footnotetext{
${ }^{5}$ Zbigniew Boniek $\mathrm{w}$ odpowiedzi na propozycję rozmowy o piłce przy kawie z ówczesną dyrektorą Ekstraklasy SA napisał tak: „a gdy z @Piechocinski rozmawiamy o pilce to nam baba niepotrzebna, $<$ hehe $>$ " (pisownia oryginalna; kobiecapilka.pl; za: twitter.com - wpis usunięty [dostęp 20.09.2020 r.]).

${ }^{6}$ W 2019 r. prezes PZPN publicznie przyznał, że planuje poważnie zainwestować w ekstraligową piłkę nożną kobiet, argumentując to w ten sposób: „dziewczyny mogą mieć takie same marzenia jak chłopcy” (wyborcza.pl [dostęp 5 października 2020 r.]). W praktyce dotacje na żeński futbol w Polsce i wynagrodzenia piłkarek są wielokrotnie mniejsze niż w przypadku mężczyzn. Ponadto dodatkowe środki przyznane przez Zbigniewa Bońka klubom kobiecym są uznawane za niewielkie, co spotyka się z krytyką m.in. trenerów (sport.pl [dostęp 3 października 2020 r.]).

${ }^{7} \mathrm{~W}$ trakcie pisania tego tekstu dotarła do mnie informacja o niedawnym skazaniu wspomnianego trenera na 3 lata pozbawienia wolności za molestowanie seksualne niepełnoletnich piłkarek Kotwicy Kórnik (poznan.wyborcza.pl [dostęp 2 października 2020 r.]).
} 
czającym zaangażowaniem osób z doświadczeniem życia jako kobiety w grę, pochodzeniem zawodniczek spoza regionu oraz ich młodym wiekiem ${ }^{8}$. Nietrudno stwierdzić, że ze strony zarządu doszło do aktu przemocy symbolicznej (Bourdieu, Wacquant 2001) i wymierzono karę wobec piłkarek za brak podporządkowania wewnętrznej polityce klubu, w ramach której stygmatyzuje się ofiary, a nie oprawcę?.

\section{Grupa i metody działania ze społecznością}

Interwencja artystyczna „Piłkarzy(n)ki” została zrealizowana w Poznaniu w 2019 roku w ramach projektu „Sąsiedztwo - granice bliskości. Queerowy Demontaż", organizowanego przez stowarzyszenie Scena Robocza. Od marca do lipca 2019 roku uczestniczyłam w comiesięcznych, weekendowych warsztatach z badaczkami, artyst(k)ami, działacz(k)ami, aktywist(k)ami oraz kuratorką i producentką projektu $\mathrm{w}$ formalnych i nieformalnych spotkaniach z grupą uczestników/uczestniczek oraz ze społecznością Poznania, w wydarzeniach artystycznych, a także w wielu rozmowach i konsultacjach $\mathrm{z}$ piłkarkami. Zwieńczeniem całego projektu miało być przeprowadzenie własnej, queerowej interwencji badawczo-artystycznej przez każdą osobę uczestniczącą. Przyjęliśmy i przyjęłyśmy, że to właśnie inkluzywna teoria queer „uwrażliwia na obecność wszystkiego, co nienormatywne, wyrzucone poza margines lub poza dominujący dyskurs seksualno-

\footnotetext{
8 Treść oświadczenia: http://www.kotwicakornik.pl/oswiadczenie-zarzadu-kss-kotwica-kornik/ [dostęp 12 lipca 2020 r.].

${ }_{9}$ O sprawie został przeprowadzony reportaż przez poznańskie Radio Afera (https://www.afera.com.pl/news/4150 [dostęp 9 lipca 2020 r.]). Pisał o niej także Codziennik Feministyczny (http://codziennikfeministyczny.pl/pilkarki-klubu-kotwicakornik-ujawniaja-molestowanie-najmlodsza-miala-12-lat/ [dostęp 9 lipca 2020 r.]).
}

ści" (Struzik 2012: 93), a także płci i działaliśmy oraz działałyśmy według jej subwersywnych założeń (Butler 2008).

Ponadto w idei „Sąsiedztwa” głęboko osadzona jest chęć rozwijania relacji z lokalną społecznością, dlatego pomysły uczestników i uczestniczek miały zostać zrealizowane w duchu sztuki ze społecznością. Jako że byłam świeżo po zakończeniu dwuletnich badań etnograficznych do pracy magisterskiej na temat żeńskiej piłki nożnej jako formy oporu wobec patriarchatu w Polsce, zdecydowałam się na działanie z piłkarkami. Samą interwencję - opracowaną według metod antropologii zaangażowanej i będącą formą badania w działaniu jako sztuki ze społecznością - mogę podzielić na trzy kluczowe etapy: (1) warsztaty projektowania figurek z lokalną społecznością Poznania podczas pikniku Queering the Future na dziedzińcu Sceny Roboczej, (2) wernisaż wystawy projektu „Sąsiedztwo - granice bliskości. Queerowy Demontaż", na którym można było zagrać w „Piłkarzy(n)ki” po raz pierwszy i (3) turniej w przestrzeni publicznej we współpracy z poznańską Galerią Arsenał, która udostępniła nam przestrzeń do działania w samym środku Starego Rynku w Poznaniu.

Od początku pracy wspierała mnie piłkarka i artystka Justyna Dziabaszewska, która w terenie pełniła funkcję „odźwiernej” (Hammersley, Atkinson 2001: 70) i wprowadzała mnie w społeczność piłkarek. Wspólnie uzgodniłyśmy, jakiego rodzaju projekt warto zrealizować i jak zrobić to tak, żeby nie zaszkodzić już poszkodowanym i skrzywdzonym piłkarkom. W całym toku działania czułam ogromną odpowiedzialność za grupę. Raymond Firth (2004) twierdzi, że duże zainteresowanie antropolożki problemami dyskutowanymi w społeczności może doprowadzić do konfliktu pomiędzy badacz- 
ką a strukturami władzy (por. Sochacki 2010), co wówczas nie miało miejsca, ale mogłoby wydarzyć się po publikacji tego artykułu. Ponadto Firth (2004) zastanawia się, czy stanowisko zaangażowane badaczy i badaczek nie wynika z paternalistycznego podejścia zakładającego, że „najlepiej wiedzą, czego trzeba społeczności” (por. Sochacki 2010). Według mnie projektowanie i realizacja działań podlegają stałym negocjacjom, ustaleniom oraz nieustannemu wsłuchiwaniu się w głos grupy. Z całą pewnością skupiałam się przede wszystkim na oddolnych akcjach inicjowanych przez społeczność, a nie na realizacji własnych, badawczych założeń. Podczas planowania poszczególnych części „Piłkarzy(n)ek” nie chciałam zrobić niczego, z czym zawodniczki by się nie zgadzały, a wiedziałam o tym, że z braku czasu nie mogą zaangażować się $\mathrm{w}$ projekt $\mathrm{w}$ pełni, dlatego podjęłam ścisłą współpracę z Justyną. To z nią konsultowałam oraz akceptowałam plany projektu, a także wszelkie zmiany - miała bezpośredni wpływ na kształt i charakter interwencji. Zorganizowała też kilkugodzinne spotkanie, podczas którego wspólnie z piłkarkami ustalałyśmy cele oraz zasady całego przedsięwzięcia. Pełniła rolę rzeczniczki drużyny, włączając resztę zdegradowanej grupy do działania czy wymyślając nazwę „Piłkarzy(n)ki”, opartą na charakterystycznej grze słów, która rzuca światło na problematyczne kwestie płci w piłce nożnej.

Poza Justyną w działaniach brały udział piłkarki, osoby zrzeszone wokół Sceny Roboczej, poznańscy artyści, artystki, badacze i badaczki, a także inni Poznaniacy i Poznanianki - osoby, które akurat zainteresowała jedna z naszych akcji w przestrzeni publicznej i postanowiły podejść, by pograć czy porozmawiać. Na wszystkich etapach pracy bardzo uważnie obserwowałam uczestniczki/ów działań. Wydarzenia były rejestrowane $\mathrm{w}$ formie krótkich filmów oraz zdjęć i publikowane na bieżąco w mediach społecznościowych tak, aby jak najlepiej i najszerzej je wypromować.

Projekt „Piłkarzy(n)ki” wpisuje się w ideę antropologii zaangażowanej, bo przyjął formę, dzięki której zabrałyśmy $\mathrm{z}$ piłkarkami głos $\mathrm{w}$ debacie publicznej i symbolicznie walczyłyśmy na rzecz równości oraz wolności (Kościańska 2004; Songin-Mokrzan 2013). Ponadto jego celem było poznanie i zrozumienie społeczno-kulturowego kontekstu, w którym grupa funkcjonuje, ale także sprowokowanie zmian $\mathrm{w}$ przestrzeni zagrażającej osobom z doświadczeniem życia jako kobiety i tym samym ingerencja w lokalny porządek symboliczny (Scheper-Hughes 1995; Songin-Mokrzan 2013). Ważne było też to, żeby w demokratyczny sposób wypracować z grupą piłkarek Kotwicy Kórnik narzędzie, które sprzyja autoemancypacji - na to właśnie pozwalają praktyki badań w działaniu jako sztuki ze społecznością (Rakowski 2018; Wójcik, Stokfiszewski, Jasińska 2018). Pracowałyśmy wedle badawczej hipotezy, że tego typu badanie przez działanie stwarza warunki, by ujawniło się to, co bardzo istotne w życiu grupy, a także ma wzbudzić niejawny wymiar twórczego działania społeczności i jej własnej, oddolnej organizacji (Rakowski 2013). Było to szczególnie widoczne podczas pierwszej, warsztatowej części interwencji, którą opisuję w kolejnych podrozdziałach tej pracy. Starałyśmy się też utrzymywać charakter badań w działaniu, który proponuje George Marcus, kiedy pisze, że proces badawczy nie polega jedynie na obserwowaniu lokalnego "terenu”, ale na tym, że powstaje zjawisko funkcjonujące na przecięciu działań badaczy i toczących się ludzkich historii. Wówczas badania terenowe "stają się bardziej spotkaniem dwóch pokrewnych sobie światów społecznych" (Marcus 2003 za: Plińska, Rakowski 2010: 89). 
Warto wspomnieć, że piłkarki były wyposażone we wspomniane instrumenty autoemancypacji, zanim zaczęłyśmy współpracę. Na własną rękę zaczęły walkę z patriarchalnym, opresyjnym zarządem klubu Kotwica Kórnik, między innymi wkraczając na drogę sądową z trenerem, który dopuszczał się molestowania seksualnego młodszych zawodniczek. Moim zadaniem było po prostu otwarcie dla nich dodatkowej przestrzeni partycypacyjnego, wspólnego działania i zjednoczenie się w problemie, który zaobserwowałam. Chciałam też zwrócić uwagę na uniwersalny charakter dyskryminacji oraz marginalizacji piłkarek w Polsce w ogóle i zachęcić innych do krytycznej refleksji na temat segregacji płci oraz (symbolicznej) przemocy w piłce nożnej. Wspólnie ze społecznością starałyśmy się wypracowywać mechanizmy, dzięki którym otworzą się oczy pozostałych, może do tej pory mniej wyczulonych na kwestie nierówności w futbolu. To na tym polegała nasza wspólna, równościowa, queerowa akcja.

\section{Mikrostadion i warsztaty projektowania figurek}

Antropologia sportu z perspektywy Honoraty Jakubowskiej (2013) traktuje stadion piłkarski jako przestrzeń, w ramach której (re)produkuje się i umacnia wspomniane hierarchiczne relacje płci. Moim zdaniem to charakterystyka nie tylko samego stadionu - należy potraktować go jako symbol wszelkich wydarzeń (około)piłkarskich rozgrywających się w naszym kraju. Dlatego zdecydowałam, że działanie ze społecznością w Poznaniu, oparte o moje wcześniejsze obserwacje i wnioski z badań przeprowadzonych w Warszawie, skupi się wokół mikrostadionu. $W$ tej sytuacji stał się nim stół do piłkarzyków z dwudziestoma dwoma biało-czerwonymi figurkami przypominającymi muskularnych mężczyzn, które znajdują się w znakomitej większości wyposażeń tej popularnej gry. Społeczność poznańska miała za zadanie przerobić te figurki tak, by utraciły swoją męską charakterystykę i aby później stały się elementem interaktywnej instalacji. Tym samym wspólnie z piłkarkami chciałyśmy pokazać skalę uprzedmiotowienia i marginalizacji kobiet grających w futbol, symbolicznie odzyskać przestrzeń oraz głos, sprzeciwić się dyskryminacji oraz degradacji żeńskiej drużyny klubu Kotwica Kórnik i szerzej - dominacji mężczyzn w sektorze piłki nożnej w Polsce.

Społeczność projektowała oraz przerabiała wspomniane figurki podczas otwartych warsztatów na pikniku Queering the Future, współorganizowanym przez stowarzyszenie Scena Robocza w 2019 roku. W warsztatach wzięli udział przechodnie, poznańskie piłkarki i sportowczynie, lokalni artyści, artystki, działacze i działaczki wraz z bliskimi, a także dzieci $\mathrm{w}$ asyście rodziców. W wyznaczonym miejscu na dziedzińcu Sceny Roboczej ustawiłyśmy stoły warsztatowe $\mathrm{z}$ materiałami ozdobnymi takimi jak farby, spraye, kolorowe tasiemki, cekiny, suszone kwiaty, plastikowe klejnoty, brokat, czyli materiały w tym zestawieniu kojarzące się z queerowościa, kwestionujące i negocjujące normy obowiązujące w piłce, nawiązujące estetycznie do wydarzeń o charakterze wolnościowym i równościowym. Każdy i każda mogła dostać tylko jedną figurkę, bo było ich niewiele, a chciałam, żeby jak najwięcej osób mogło się włączyć. Przez to powstało wiele prac zbiorowych, kiedy nad jedną postacią wspólnie pracowały partnerki, mama z córką, ojciec z synem albo para heteronormatywna. Animowałam całe wydarzenie, instruowałam uczestników i uczestniczki, pomagałam i zachęcałam do korzystania $\mathrm{z}$ makiet $\mathrm{w}$ formie wydruku czarnego konturu figurki, na który można było na- 
nieść projekt tego, co powstanie później w formie przestrzennej. Niewiele osób skorzystało z tej możliwości. Większość od razu brała się do działania.

Każdą osobę uczestniczącą starałam się wprowadzić w temat sytuacji piłkarek w Polsce, aby umiejscowić akcję w szerszym kontekście społeczno-kulturowym. Mówiłam, że żeński futbol jest dyskryminowany i marginalizowany, a na warsztatach zrobimy coś, co ma uwidocznić kobiety w piłce nożnej oraz pomóc w uchwyceniu ich głosu. W zadaniu najważniejsze było to, żeby jak najdalej odejść od dominującego wzorca białego, muskularnego, heteronormatywnego mężczyzny i urzeczywistnić swoją wizję piłkarki. Pytałam uczestników i uczestniczki, jak widzą piłkarkę, z czym im się kojarzy oraz jaka ich zdaniem powinna być i dlaczego. Tłumaczyłam, że figurki mogą przybrać wygląd osoby z doświadczeniem życia jako kobiety, także niebinarnej. Najchętniej korzystano z kolorowych materiałów, z pomponów i różnych przestrzennych, miękkich, ozdobnych elementów. Dzięki temu figurki zaczęły wyglądać tak, jakby ich stroje miały amortyzować uderzenia piłki albo ewentualne upadki. Można wywnioskować, że osoby uczestniczące starały się ocieplić wizerunek piłki kojarzonej z męskością, ale także dać wyraz odrębności, przekraczania granic oraz norm wizualnych, płciowych i seksualnych obowiązujących na boisku.

Sytuacja warsztatowa, czyli praktyka działania z zakresu sztuki ze społecznością, z pewnością mogłaby wpisać się w część "zwrotu performatywnego", czyli przejścia od indywidualnego tworzenia dzieła sztuki do wydarzenia kolektywnego o zbiorowym charakterze (Stokfiszewski 2018). Jednostki projektowały postaci, które z założenia miały funkcjonować jako całość. Zanim figurki trafiły na piłkarzy(n) kowy stół, leżała na nim ilustrowana książka Kobie- ty $i \operatorname{sport}^{10}$, po którą chętnie sięgano przy oddawaniu swojego projektu. Wszystkie osoby zostały poinformowane, że ich figurki staną się częścią interaktywnej, badawczo-artystycznej instalacji i będzie można nimi po prostu grać, aby przez pryzmat popularnej, towarzyskiej gry opowiedzieć historię o wykluczeniu i symbolicznej przemocy (Bourdieu, Wacquant 2001). Podczas pracy uczestniczki i uczestnicy nierzadko dziwili się, że wcześniej nie podjęli namysłu nad tym, jakiej płci są piłkarzyki, którymi wielokrotnie grali. Odniosłam wrażenie, że cieszyli się, mogąc być częścią działania, które wykorzystuje symboliczny kapitał sztuki w celu wprowadzenia konstruktywnej zmiany społecznej (Bishop 2015; Stokfiszewski 2018) i tym samym próbuje odwrócić dominujący dyskurs. Nie jesteśmy przecież w stanie wprowadzać zmian, zanim nie zauważymy kulturowo-społecznych nieprawidłowości albo niesprawiedliwości wokół siebie.

\section{Nigdy wcześniej nie myślałem, „że to są sami faceci"}

Premiera gotowego obiektu do gry w ramach działania „Piłkarzy(n)ki” miała miejsce podczas wernisażu wystawy „Sąsiedztwa”. Połączyłyśmy instalację ze słuchowiskiem, do którego sama napisałam tekst w oparciu o moje obserwacje i analizy kontekstu społeczno-kulturowego, a także i wcześniejsze badania na temat żeńskiego futbolu. Na dziedzińcu Sceny Roboczej ponownie stanął stół, ale tym razem kompletny - wyposażony w figurki, które wykonała społeczność. Wokół stołu położyłyśmy poduszki ze sztucznej trawy, które miały imitować murawę, tym samym wydzielając pole interaktywnej instalacji. Z początku odwiedzający nie chcieli dotykać stołu,

\footnotetext{
${ }^{10}$ Aut. Rachel Ignotofsky (2018) Kobiety i sport. Przełożyła Paulina Błaszczykiewicz. Warszawa: Egmont.
} 
przyjmując, że jest obiektem muzealnym, ale po zachęceniu zaczęli rozgrywać mecze. Na poduszkach rozsiadało się coraz więcej osób i odniosłam wrażenie, że słuchowisko, które odtwarzane było w zapętleniu, wprawiało obecnych w lekki dyskomfort.

Pozornie neutralna politycznie i niezobowiązująca gra nagle stała się narzędziem emancypującym (Stokfiszewski 2018), uświadamiającym skalę dyskryminacji, marginalizacji i przemocy wobec piłkarek nożnych, a także kobiet w ogóle. Ów tekst wprowadzał w mikroświat braku uprzywilejowania, w którym osoby z doświadczeniem życia jako kobiety grające w piłkę żyją na co dzień i wzywał do zaangażowania. Podkreśliłam w nim odwagę piłkarek w kwestii burzenia genderowych stereotypów i wymykania się tradycyjnym wzorcom płciowym, które łączą futbol najczęściej z białymi, muskularnymi, heteroseksualnymi mężczyznami (Pfister 2011). Wskazałam związek przyczynowo-skutkowy pomiędzy mizoginią i segregacją płciową w sporcie a kapitalistycznym podziałem pracy, który generuje poważne nierówności ${ }^{11}$, wzmacniając rzekomą

\footnotetext{
${ }^{11}$ Relacja nierówności i zależności płci ma oczywiście swoje głębsze korzenie - jest pochodną istniejącego w społeczeństwie kapitalistycznym podziału na sferę produkcji (aktywność mężczyzn) i reprodukcji (aktywność kobiet), co stanowi odbicie sfer publicznej (przypisanej kulturowo mężczyznom) i prywatnej (przypisanej kobietom) (Engels 1884; Firestone 1970; Collier, Ronaldo, Yanagisako 2007). Ów podział nie istniał $\mathrm{w}$ czasach przed kapitalizmem, kiedy to i kobiety, i mężczyźni brali udział w procesach produkcji. Dopiero pojawienie się własności prywatnej (jako własności mężczyzn) w jakiś sposób zepchnęło kobiety do sfery nieodpłatnej pracy reprodukcyjnej, generując nierówności w tej sferze i na wielu innych polach. Wówczas kobiety wraz z dziećmi stały się „własnością" mężczyzn (Engels 1884; Firestone 1970; zob. Grabowska 2013; por. Collier, Rosaldo, Yanagisako 2007).

Przedstawicielki płci żeńskiej były (i niektóre do dziś są) ubezwłasnowolnione pod wieloma względami, m.in. ekonomicznym czy cielesnym. Odseparowano je, a nawet $\mathrm{w}$ jakiś sposób kulturowo zakazano uczestnictwa w sferze publicznej. Przez to nie mogły nie tylko pracować czy
}

niższość kobiet (Engels 1884; Firestone 1970; zob. Grabowska 2013; por. Collier, Rosaldo, Yanagisako 2007).

Jednym z ciekawszych momentów tego wydarzenia była rozmowa, którą odbyłam przy stole piłkarzy(n)kowym z mężczyzną około czterdziestoletnim. Mówił o tym, że często gra ze swoimi kilkuletnimi synami w piłkarzyki, ale nigdy wcześniej nie zastanawiał się, "że to są sami faceci" i sam z siebie zapewniał, że poruszy ten temat z dziećmi w rozmowie uświadamiającej o problemie. Mężczyzna przypomniał mi wówczas o moich warszawskich badaniach, w których zazwyczaj już na samym początku rozmów z piłkarkami pytałam je o to, kiedy i dlaczego zaczęły grać w futbol. W większości przypadków herstoria grania rozpoczynała się właśnie we wczesnym dzieciństwie. Prawie wszystkie moje rozmówczynie od małego z zapałem kopały piłkę pod blokiem, na podwórku, na ogólnodostępnym boisku lub w szkolnej sali gimnastycznej. Grały też w piłkarzyki. Wydarzenia z dziecięcych czasów w znaczącym stopniu wpłynęły na obecne podejście piłkarek do sportu, ukształtowały je i zdeterminowały. Według australijskiej badaczki społecznej Lynne Hillier (2005), owe doświadczenia z dzieciństwa są kluczem do zrozumienia tego, w jaki sposób przekracza się pewne ograniczenia związane z płciowością, a w szczególności - z byciem kobie-

jakkolwiek udzielać się politycznie albo społecznie, ale też decydować o tym, co chcą zrobić ze swoim ciałem. W związku z tym z całą pewnością publicznie „nie wypadało" im też uprawiać sportu. Ten zarezerwowany był dla mężczyzn. Ponadto amerykańska badaczka Susan Birrell zwraca uwagę na fakt, że sport jest silnym narzędziem ideologicznym, niezbędnym wręcz do (re)produkowania dominacji mężczyzn nad kobietami. Co za tym idzie - wyznaczone np. przez piłkę nożną granice płci i ról płciowych podtrzymują wyżej opisany podział pracy, od którego zależy stabilność jakiegoś porządku społecznego (Birrell 1988). 
tą grającą w piłkę nożną. U moich rozmówczyń już w latach młodzieńczych wykształcały się postawy kwestionujące "tradycyjne” wzorce kobiecości. Dziewczyny na swój sposób opierały się podziałom i segregacji płci, zwłaszcza w sporcie. Wydało mi się to niezwykle ważne, żeby także z chłopcami albo dziećmi czy młodzieżą o innej tożsamości płciowej rozmawiać o kwestii reprodukowania podobnych postaw.

\section{Turniej w centrum, nie na „kartoflisku”}

Częścią trzecią, ostatnią i zamykającą całą interwencję artystyczną, był turniej „Piłkarzy(n)ek” w przestrzeni publicznej, a konkretnie przy Galerii Arsenał, w samym środku Starego Rynku w Poznaniu. Justyna Dziabaszewska z tej okazji napisała post na Facebooku, który zachęcał do przyjścia i wspólnej gry:

\section{Kochane osoby!}

W czwartek odbędzie się Wielki Finał projektu Piłkarzy(n)ki! Zagramy Turniej na obiekcie specjalnie zaprojektowanym na tą okazję. Poprzez grę figurkami reprezentującymi kobiety i inne tożsamości, dla których brakuje miejsca w piłce nożnej, wspólnie zaprotestujmy przeciwko dyskryminacji w futbolu! Zapraszam przede wszystkim wszystkie piłkarki, które nie godzą się na lekceważące traktowanie przez władze swoich klubów, PZPN i media głównego nurtu. Spotykamy się na samym środku Starego Rynku nie przez przypadek, symbolicznie odzyskujemy dla siebie przestrzeń, po latach gry na peryferiach, „kartofliskach", poza orbitą zainteresowań środowiska piłkarskiego. W czwartek zagramy w samym centrum. Tym radosnym akcentem zaznaczymy swoją obecność, przy okazji poznamy się lepiej i zastanowimy, jak walczyć o swoje prawo do gry! (pisownia oryginalna; facebook.com [dostęp 20 lipca 2020 r.])
W performatywną akcję włączyła się duża grupa piłkarek żeńskiej drużyny klubu Kotwica Kórnik, ale także osoby, które akurat przechodziły niedaleko. Wychodząc z obiektem „Piłkarzy(n)ki” w przestrzeń publiczną, weszłyśmy do niej jednocześnie z wykluczanymi osobami z doświadczeniem życia jako kobiety. Każdy mógł w tę grę zagrać, wysłuchać towarzyszącego, feministycznego słuchowiska i porozmawiać o binarnych podziałach i segregacji płciowej w piłce. Na ten moment zrobiłyśmy z przestrzeni publicznej tak zwaną safe space, czyli bezpieczną przestrzeń, obszar wspólnoty, przynależności, budowania tożsamości, gdzie zakwestionowane zostały banalne stereotypy płciowe (Fine, Bertram 1999). Dzięki temu symbolicznie odzyskałyśmy miejsce do gry. Działając w duchu antropologii zaangażowanej i sztuki ze społecznością, postawiłyśmy sobie za cel zburzenie istniejącego porządku, który według nas „wytwarza i reprodukuje nierówności zarówno na poziomie struktury społecznej, jak i w sferze dyskursywnej" (Songin-Mokrzan 2014: 40). Udało nam się w jakiś sposób poruszyć skostniałą społeczną tkankę i rozszerzyć granice dotychczas zamkniętej grupy.

Na uwagę zasługuje sytuacja, w której, już po zakończonym turnieju, musiałyśmy z Justyną odwieźć obiekt do Sceny Roboczej. Weszłyśmy ze stołem piłkarzy(n)kowym do tramwaju, a siedzący w nim wówczas ludzie, ot tak, zaczęli z nami rozgrywać mecz. Był to przykład na to, o czym pisze Karolina Izdebska (2018), że sztuka ze społecznością ma przekształcać relacje społeczne i uruchamiać wśród jej uczestników nowe, a także nie ograniczać poczucia ich sprawczości. Takie relacje budują się w sytuacji warsztatowej, ale także w toku spontanicznego współdziałania. W opisywanej sytuacji oprócz rozegrania tramwajowego meczu wymieniłyśmy z uczestniczącymi serdecz- 
ne spojrzenia, uśmiechy i komentarze na temat gry. Nagle w środku transportu, czyli w przestrzeni niemiejsca, miejsca niczyjego, w którym rzadko dochodzi do zawierania relacji społecznych (Augé 2011), nawiązałyśmy bezpośredni kontakt. Według mnie było to ciekawe o tyle, że obiekt demokratyzujący piłkę nożną w Polsce i zwracający uwagę na problem wykluczenia i segregacji w futbolu mógł przyczynić się choćby do chwilowej integracji zupełnie obcych osób. Żeńska piłka nożna na dobre weszła do przestrzeni publicznej i wbrew popularnym przesłankom - wszyscy wówczas chcieli ją oglądać. Oczywiście była to absolutnie niecodzienna sytuacja, ale mimo wszystko została podkreślona nienormatywnym wyglądem figurek, odbiegającym od dominującego wzorca piłkarza lub piłkarzyka, co było celem akcji.

\section{Podsumowanie}

Zdaniem Raewyn Connell (2013: 29-30) istnieje coś takiego jak patriarchalna struktura relacji płci, w ramach której praktyki polityczne, religijne i konwersacyjne przyznają mężczyznom władzę nad kobietami. Owe relacje powstały i mogą nadal powstawać dlatego, że współcześnie wciąż angażujemy się $\mathrm{w}$ „upłciowione tryby zachowania” (Hagemann-White 1987 za: Connell 2013: 29-30). Dopóki nie postaramy się załamać tradycyjnego, hegemonicznego wzorca, łączącego z piłką nożną przeważnie mężczyzn, to praktyki dyskryminujące prawdopodobnie będą tylko rosły w siłę. Swoim artykułem starałam się zachęcić do podjęcia postawy zaangażowanej w naukach humanistyczno-społecznych i pokazać, jak inicjatywa z zakresu

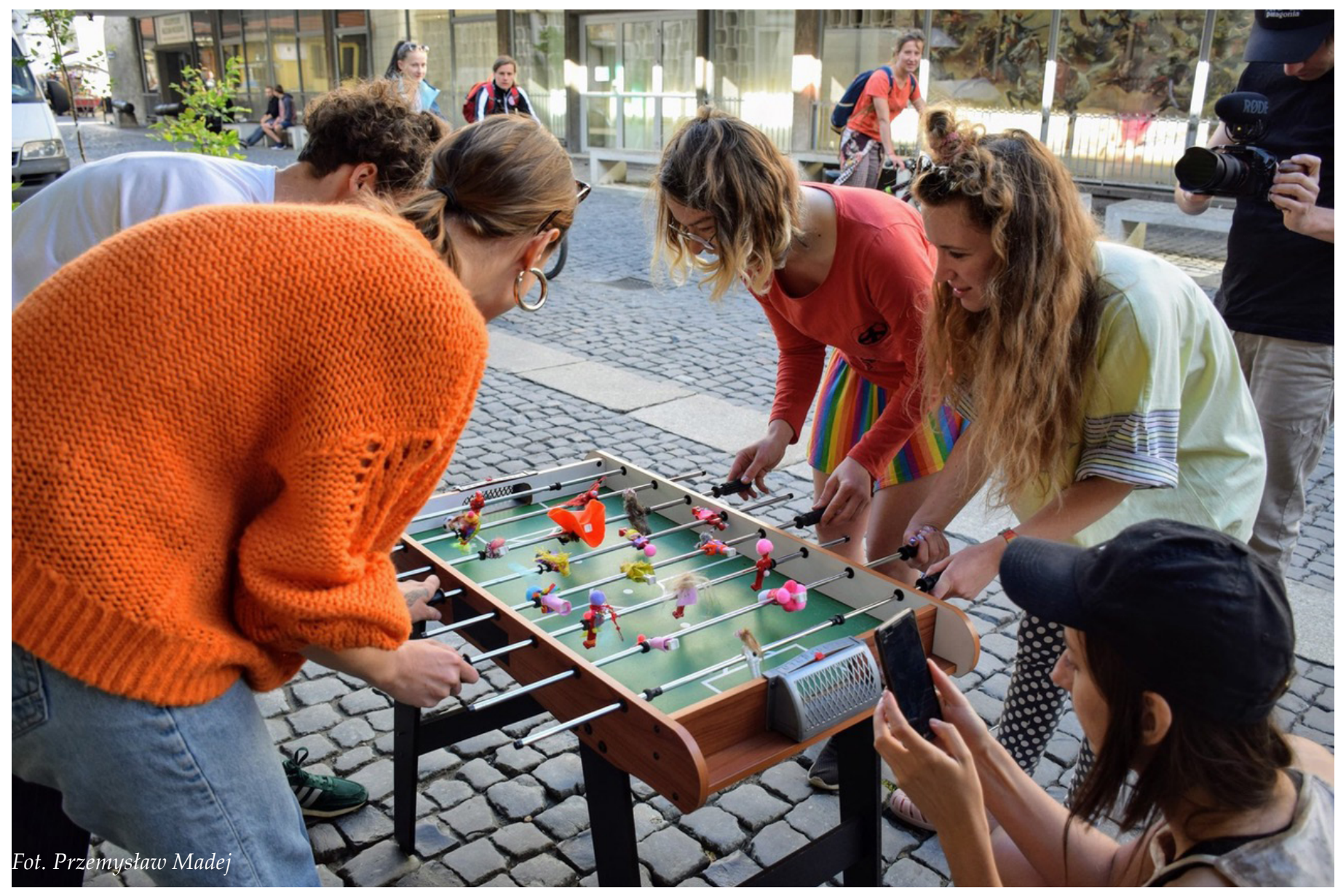


antropologii zaangażowanej i badań w działaniu jako sztuki ze społecznością może pomóc w uchwyceniu głosu piłkarek nożnych, dyskryminowanych w Polsce. Cała interwencja badawczo-artystyczna oraz obiekt „Piłkarzy(n)ki” są pewną metaforą zamknięcia piłkarek w mikroprzestrzeni i ulokowania ich działalności na marginesie. Jednocześnie zwracają uwagę na problem uprzedmio-

\section{Bibliografia}

Augé Marc (2011) Nie-miejsca. Wprowadzenie do antropologii hipernowoczesności. Przełożył Roman Chymkowski. Warszawa: Wydawnictwo Naukowe PWN.

Birrell Susan (1988) Discourses on the Gender/Sport Relationship: From Women in Sport to Gender Relations. "Exercise and Sport Sciences Reviews", vol. 16, s. 459-502.

Bishop Claire (2015) Sztuczne piekta. Sztuka partycypacyjna i polityka widowni. Przełożył Jacek Staniszewski. Warszawa: Fundacja Nowej Kultury Bęc Zmiana.

Bourdieu Pierre, Wacquant Loic J. D. (2001) Zaproszenie do socjologii refleksyjnej. Przełożyła Anna Sawisz. Warszawa: Oficyna Naukowa.

Butler Judith (2008) Uwikłani w płeć. Feminizm i polityka tożsamości. Przełożyła Karolina Krasuska. Warszawa: Wydawnictwo Krytyki Politycznej.

Caudwell Jayne (2003) Sporting Gender: Women's Footballing: Bodies as Sites/Sights for the (Re)Articulation of Sex, Gender, and Desire. "Sociology of Sport”, vol. 20, s. 371-386.

Červinková Hana (2012) Badania w działaniu i zaangażowana antropologia edukacyjna. „Teraźniejszość - Człowiek - Edukacja”, t. 1 , nr 57, s. $7-15$.

Collier Jane Fishburne, Rosaldo Michelle Z., Yanagisako Sylvia (2007) Czy rodzina istnieje? Nowe ujęcia antropologiczne towienia, wykluczenia, umniejszania ich rangi, protekcjonalnego traktowania i tym samym informują nas, jak ukształtowany jest podział władzy w ramach futbolu i porządek płci w Polsce. Projekt piętnuje nierówności, wzywa do podjęcia postawy zaangażowanej oraz pomaga symbolicznie odzyskać przestrzeń. To publiczny akt sprzeciwu i oporu wobec dominacji mężczyzn.

[w:] Renata E. Hryciuk, Agnieszka Kościańska, red., Gender. Perspektywa antropologiczna, t. 1. Organizacja społeczna. Warszawa: Wydawnictwa Uniwersytetu Warszawskiego, s. $60-75$.

Connell Raewyn, Messerschmidt James W. (2005) Hegemonic masculinity: Rethinking the concept. "Gender and Society", vol. 19, no. 6, s. 829-859.

Connell Raewyn (2013) Socjologia płci. Płeć w ujęciu globalnym. Przełożyła Olga Siara. Warszawa: Wydawnictwo Naukowe PWN, s. 15-60.

Criado Perez Caroline (2020) Niewidzialne kobiety. Jak dane tworza świat skrojony pod mężczyzn. Przełożyła Anna Sak. Kraków: Karakter.

de Certeau Michel (2008) Wynaleźć codzienność: sztuki działania. Przełożyła Katarzyna Thiel-Jańczuk. Kraków: Wydawnictwo UJ.

Dufur Mikaela J., Linford Matthew K. (2010) Title IX: Consequences for Gender Relations in Sport. "Sociology Compass”, vol. $4 / 9$, s. $732-748$.

Dzik Aleksandra (2008) Kobieta w męskim świecie - konflikt czy spójność ról? Studium socjologiczne kobiet uprawiających "męskie" sporty. Na przykładzie wspinaczki wysokogórskiej, narciarstwa wysokogórskiego oraz ekstremalnych rajdów przygodowych. „Przegląd Socjologii Jakościowej", t. 4, nr. 1, s. 116-135. 
Engels Fryderyk (1884) The Origin of the Family, Private Property and the State. Chicago: Charles H. Kerr \& Company.

Fasting Kari (2003) Small country - Big Results. Women's Football in Norway. "Soccer and Society”, vol. 4, no. 2-3, s. 149-161.

Fine Michelle, Bertram Corrine (1999) Sexing the globe [w:] D. Epstein, J. Sears, eds., A dangerous knowing: Sexuality, pedagogy and popular culture. London: Cassell, s. 153-163.

Firestone Sulamith (1970) Dialectic of Sex: A Case for Feminist Revolution. New York: Morrow.

Firth Raymond (2004) Czy antropologia społeczna ma przyszłość? [w:] Marian Kempny, Ewa Nowicka, red., Badanie kultury. Elementy teorii antropologicznej. Warszawa: PWN, s. 24-25.

Grabowska Magdalena (2013) Od "gender" do "transgender": ewolucja kategorii płci społeczno-kulturowej w naukach społecznych i prawie międzynarodowym. Warszawa: Towarzystwo Edukacji Antydyskryminacyjnej.

Grześkowiak Kamila (2014) Kto kopie jak baba? Renegocjowanie pozycji kobiet w sporcie na przykładzie piłki nożnej [w:] Michał Buchowski, Małgorzata Z. Kowalska, red., Nie tylko piłka w grze. Antropologiczne reprezentacje EURO 2012. Poznań: Wydawnictwo Nauka i Innowacje, s. 143-161.

Hammersley Martyn, Atkinson Paul (2001) Metody badań terenowych. Przełożył Sławomir Dymczyk. Poznań: Wydawnictwo Zysk i S-ka.

Hillier Lynne (2005) Safe Spaces: The Upside of the Image Problem for Same Sex Attracted Young Women Playing Australian Rules Football. „Football Studies”, vol. 8, s. 51-64.

Hryciuk Renata, Korolczuk Elżbieta (2012) Pożegnanie z Matka Polka? Dyskursy, praktyki $i$ reprezentacje macierzyństwa we współczesnej Polsce. Warszawa: Wydawnictwa Uniwersytetu Warszawskiego.

Izdebska Karolina (2018) Budowanie i splatanie, czyli społeczność jako "twórcza materia". Z zapisków badaczki [w:] Jaśmina Wójcik, Igor Stokfiszewski, Izabela Jasińska, red., Sztuka ze społecznościa. Warszawa: Wydawnictwo Krytyki Politycznej, s. $98-115$.

Jacobs Barbara (2004) The Dick, Kerr's Ladies. London: Robinson.

Jakubowska Honorata (2006) Kobiety i piłka nożna. „Czas Kultury", t. 2, s. 18-38.
Jakubowska Honorata (2013) Sport kobiet $i$ mężczyzn: uwarunkowania, różnice, granice. "Człowiek i Społeczeństwo", t. 36, s. $7-10$.

Jakubowska Honorata (2015) Dlaczego kobiety nie oglądaja piłki nożnej kobiet [w:] R. Kossakowski, J. Kurowski, J. Nowakowski, red., Modern futbol a świat kibiców. Pszczółki: Wydawnictwo Orbis Exterior, s. 71-88.

Kościańska Agnieszka (2004) Ku odpowiedzialności. Etnologia w Polsce: tradycje i wyzwania. „Maszyna interpretacyjna. Pismo kulturalno-społeczne", t. 6-7, nr 19-20, s. 12-13.

Ogrodzka Dorota (2020) Pytania o kobiecość we wsiach Zaława i Cukrówka „Kultura oddolna” [dostęp 27 września 2020]. Dostępny w Internecie: https://kulturaoddolna.pl/pytania-o-kobiecosc/.

Pawłowska Kinga (2017) The Power of the Weak: Strategies of Power and Tactics of Resistance in Organization. "Social Studies: Theory and Practice", t. 3, s. 39-60.

Pfister Gertrude (2011) Women in Sport - Gender Relations and Future Perspectives [w:] Richard Giulianotti, ed., Sociology of Sport, vol. 2. Social Divisions and Conflicts in Sport. Los Angeles, London, New Delhi, Singapore, Washington: SAGE, s. $57-74$.

Plińska Weronika, Rakowski Tomasz (2010) Etnografia jako dziatanie społecznelanimacja kultury. „Prace Etnograficzne. Zeszyty Naukowe Uniwersytetu Jagiellońskiego, t. 38, s. 85-93.

Rakowski Tomasz (2013) Etnografialanimacja/sztuka. Obrona metodologiczna. „Stan rzeczy”, t. 4, s. 38-63.

Rakowski Tomasz (2018) Wieś, podmiotowości, działanie: sztuka wśród społeczności (community arts) [w:] Jaśmina Wójcik, Igor Stokfiszewski, Izabela Jasińska, red., Sztuka ze społecznościa. Warszawa: Wydawnictwo Krytyki Politycznej, s. 74-96.

Scheper-Hughes Nancy (1995) The Primacy of the Ethical. Propositions for a Militant Anthropology. "Current Anthropology”, vol. 36, s. 409-440.

Sochacki Łukasz (2010) Antropologia zaangażowana (?). „Prace etnograficzne. Zeszyty Naukowe Uniwersytetu Jagiellońskiego", t. 38 , s. 7-16.

Songin-Mokrzan Marta (2013) Antropologia zaangażowana w Polsce. Poza postmodernistyczna koncepcje nauki. „Lud”, t. 97, s. 111-132. 
Songin-Mokrzan Marta (2014) Zwrot ku zaangażowaniu. Strategie konstruowania nowej tożsamości antropologii. Wrocław: Polskie Towarzystwo Ludoznawcze.

Stokfiszewski Igor (2018) Sprawczość wspólnoty. W stronę radykalnego programu sztuki ze społecznościa [w:] Jaśmina Wójcik, Igor Stokfiszewski, Izabela Jasińska, red., Sztuka ze społecznością. Warszawa: Wydawnictwo Krytyki Politycznej, s. 14-51.

Struzik Justyna (2012) Publiczna socjologia queer. „Studia Humanistyczne AGH", t. 11/2, s. 93-103.
Suchocka Agnieszka (2011) Przemoc symboliczna jako element ukrytego programu kształcenia polskiej szkoty. „Zeszyty Naukowe AMW", t. 4, s. 293-302.

Williams Jean (2007) A Beautiful Game: International Perspectives on women's football. Oxford: Berg.

Wójcik Jaśmina, Stokfiszewski Igor, Jasińska Izabela, red. (2018) Sztuka ze społecznością. Warszawa: Wydawnictwo Krytyki Politycznej.

\title{
Cytowanie
}

Krauz Wika (2021) Jakiej płci sa piłkarzy(n)ki? Żeński futbol i antropologia zaangażowana. „Przegląd Socjologii Jakościowej”, t. 17, nr 1, s. 56-70 [dostęp dzień, miesiąc, rok]. Dostępny w Internecie: 〈www.przegladsocjologiijakosciowej.org〉. DOI: http://dx.doi. org/10.18778/1733-8069.17.1.05

\section{What Gender Are Foosball Figurines? Women's Soccer and Engaged Anthropology}

\begin{abstract}
The article concerns the author's "Foosball Figurines" project - a queer-feminist art intervention and a game facility created with the local community in Poznań. The project emerged following a two-years-long ethnographic research (2016-2018) about the marginalization of female football in Poland. I applied the methodology and theory of engaged anthropology (Scheper-Hughes 1995) as well as action research perceived as community arts (Červinková 2012; Bishop 2015; Rakowski 2018), simultaneously subjecting these research trends to critical reflection. This article shows how an initiative that combines research and action helps to capture the voices of discriminated soccer players. This project is a response to the binary gender division and inequality in football, the symbolic violence (Bourdieu, Wacquant 2001), and the unjustified degradation experienced by the female soccer players of the Kotwica Kórnik club. In the paper herein, I put forward the thesis that football is a social lens that shows how the gender order within the Polish society is shaped.
\end{abstract}

Keywords: anthropology of sport, football, gender anthropology, community arts, engaged anthropology 